\title{
Expression of VEGF-A/C, VEGF-R2, PDGF- $\alpha / \beta$, c-kit, EGFR, Her-2/Neu, Mcl-1 and Bmi-1 in Merkel cell carcinoma
}

\author{
Markus Brunner ${ }^{1}$, Dietmar Thurnher ${ }^{1}$, Johannes Pammer², Silvana Geleff², \\ Gregor Heiduschka ${ }^{1}$, Christina M Reinisch ${ }^{3}$, Peter Petzelbauer ${ }^{3}$ and Boban M Erovic ${ }^{1}$ \\ ${ }^{1}$ Department of Otorhinolaryngology, Head and Neck Surgery, Medical University of Vienna, Vienna, \\ Austria; ${ }^{2}$ Department of Clinical Pathology, Medical University of Vienna, Vienna, Austria and ${ }^{3}$ Department \\ of Dermatology, Medical University of Vienna, Vienna, Austria
}

\begin{abstract}
Merkel cell carcinoma is a rare but very aggressive tumor of the skin. With current treatment options, Merkel cell carcinoma is associated with a high incidence of recurrence and metastasis. Targeted anticancer therapies such as receptor tyrosine kinase inhibitors and antisense oligonucleotides have been found to be a promising new type of treatment for various types of cancer. To evaluate whether the use of targeted therapies is a possible treatment option in Merkel cell carcinoma, we determined the expression of the target molecules c-kit, Mcl-1, Bmi-1, vascular endothelial growth factor (VEGF)-A, VEGF-C, VEGF-receptor 2 (VEGF-R2), plateletderived growth factor (PDGF)- $\alpha$, PDGF- $\beta$, epidermal growth factor receptor (EGFR) and Her-2/Neu in a tissue microarray of 32 samples of 29 patients with Merkel cell carcinoma. C-kit-positive samples were analyzed for mutations in exons 9 and 11. The tissue microarray was stained immunohistochemically with antibodies directed against the above-mentioned proteins, and an immunoreactivity score was calculated. DNA was extracted from c-kit-positive samples and was analyzed for exon 9 and 11 mutations using direct DNA sequencing. We found that c-kit (7\%), Mcl-1 (88\%), Bmi-1 (78\%), VEGF-A (91\%), VEGF-C (75\%) VEGF-R2 (88\%), PDGF- $\alpha(72 \%)$ and PDGF- $\beta(13 \%)$ were expressed in Merkel cell carcinomas. All samples showed a lack of EGFR and Her-2/Neu expression. Analysis of c-kit revealed no mutations. As VEGF-A, VEGF-C, VEGF-R2, PDGFs and c-kit are targets of new cytostatic agents used in the treatment of other cancers, inhibition by a multitargeted chemotherapy could be a very promising treatment option. High expression of Bmi-1 and Mcl-1 warrants further studies on the use of antisense oligonucleotides in Merkel cell carcinoma.
\end{abstract}

Modern Pathology (2008) 21, 876-884; doi:10.1038/modpathol.2008.63; published online 11 April 2008

Keywords: Merkel cell carcinoma; targeted therapies; receptor tyrosine kinase; c-kit; Bmi-1; Mcl-1

Most cases of Merkel cell carcinoma occur in elderly people with the average age of presentation being 69 years. ${ }^{1}$ Increased frequency has been reported in sun-exposed parts of the body and after immunosuppression. According to the US Surveillance Epidemiology and End Results Program (SEER database), the estimated incidence per 100000 people is 0.23 in the white population and 0.01 in the black population. ${ }^{1,2}$ Although many small studies have been published on the treatment of Merkel cell carcinoma, so far no gold standard has been established. ${ }^{3}$ Current treatment options are

Correspondence: Dr BM Erovic, MD, Department of Otorhinolaryngology, Head and Neck Surgery, Medical University of Vienna, Währinger Gürtel 18-20, Wien, Vienna 1090, Austria.

E-mail: boban.erovic@meduniwien.ac.at

Received 03 January 2008; revised 19 February 2008; accepted 27 February 2008; published online 11 April 2008 surgery alone, radiotherapy alone or surgery with postoperative radiotherapy. Owing to the rareness of the disease, very little data are available on the efficacy of chemotherapy and the results are conflicting. ${ }^{4,5}$ Overall 5-year survival ranges from 31 to $74 \%{ }^{6}$

Targeted anticancer therapies have been found to be very promising options in the treatment of different forms of cancer such as renal cell carcino$\mathrm{ma}^{7,8}$ and gastrointestinal stromal tumors. ${ }^{9,10}$ So far no clinical trials using small molecules for Merkel cell carcinoma have been published. Moreover, data available on the expression of possible therapy targets in Merkel cell carcinoma are very limited. Only c-kit, a receptor tyrosine kinase, was found to be expressed in 15-90\% of Merkel cell carcinoma samples. ${ }^{11-16}$

In the present study, we have assessed the expression of the possible molecular targets vascular 
endothelial growth factor (VEGF)-A, VEGF-C, VEGFreceptor 2 (VEGF-R2), platelet-derived growth factor (PDGF)- $\alpha$ and PDGF- $\beta$, epidermal growth factor receptor (EGFR), Her-2/Neu (c-erbB-2), c-kit (CD117), Mcl-1 and Bmi-1 in 32 samples of Merkel cell carcinoma to determine if targeted therapy could be a possible treatment option. C-kit-positive samples were analyzed for the most common mutations in exons 9 and 11 using direct DNA sequencing.

\section{Materials and methods}

\section{Patients}

Thirty-two archival samples of Merkel cell carcinoma of 29 patients (mean age 76.5 years, 17 male, 12 female) from the Department of Otorhinolaryngology, Head and Neck Surgery and Department of Dermatology of the Vienna Medical
University were included in the study. Patients' clinical data are shown in Table 1. All samples were staged according to the most commonly used system proposed by Yiengpruksawan et $a l^{17}$ indicating (i) stage I: local disease, (ii) stage II: loco-regional disease and (iii) stage III: distant disease.

\section{Tissue Microarray}

Before analysis, H\&E-stained sections from each sample were evaluated and the suitability of inclusion for the study was determined. Sections $(2-3 \mu \mathrm{m})$ were used for the analysis. The suitability of the tissue was evaluated using a number of inclusion criteria such as the size (1-2 mm in depth and at least $5 \mathrm{~mm}$ in length and width), as well as other features such as appropriate fixation, absence of significant electrosurgical device lesions, signs of acidic decalcifying agents and the presence of

Table 1 Clinical data of 29 patients with Merkel cell carcinoma

\begin{tabular}{|c|c|c|c|c|c|c|c|c|c|c|}
\hline$S / P$ & Туре & Site & Stage & 1st treatment & Rec. (months) & 2nd treatment & 3rd treatment & Status & $T L F$ & IS \\
\hline $1 / 1$ & Primary & Hand & I & Surgery & & & & DOC & 7 & Yes \\
\hline $2 / 2$ & Primary & Nose & $\mathrm{I}$ & RT (64) & & & & AW & 48 & No \\
\hline $3 / 3$ & Meta & Foot & III & Surgery & Local (4)/metastasis (7) & Chemotherapy ${ }^{\mathrm{a}}$ & Chemotherapy ${ }^{b}$ & DOD & 24 & Yes \\
\hline $4 / 4$ & Primary & Thigh & I & Surgery & Metastasis (4) & RT (30) & & DOC & 36 & No \\
\hline $5 / 5$ & Meta & Cheek & I & Surgery & Local (6)/metastasis (11) & Surgery+RT & Endoxan & DOD & 18 & No \\
\hline $6 / 6$ & Primary & Lid & I & Surgery & & & & AW & 56 & No \\
\hline $7 / 7$ & Meta & Cheek & II & Surgery & Metastasis (6) & RT (60) & & DOD & 24 & Yes \\
\hline $8 / 8$ & Meta & Elbow & $\mathrm{I}$ & Surgery & Metastasis (14) & Chemotherapy $^{\mathrm{c}}$ & RT (50) & AW & 30 & Yes \\
\hline $9 / 8$ & Meta & Chest & & & & & & & & \\
\hline $10 / 9$ & Primary & Face & II & Surgery+RT (50) & Metastasis (2) & & RT (30) & DOD & 6 & No \\
\hline $11 / 10$ & Primary & Cheek & I & Surgery+RT (30) & & & & DOC & 18 & Yes \\
\hline $12 / 11$ & Primary & Lid & I & Surgery+RT (30) & Metastasis (37) & Surgery & RT (50) & AWD & 53 & No \\
\hline $13 / 11$ & Meta & Neck & & & & & & & & \\
\hline $14 / 12$ & Meta & Lid & I & Surgery & Metastasis (14) & Surgery & & AW & 24 & No \\
\hline $15 / 13$ & Meta & Thigh & I & Surgery & Metastasis (3) & Surgery+RT (56) & Chemotherapy $^{\mathrm{d}}$ & DOD & 50 & No \\
\hline $16 / 14$ & Meta & Leg & II & Surgery & Metastasis (4) & RT (46) & Chemotherapy $^{\mathrm{a}}$ & AWD & 10 & Yes \\
\hline $17 / 15$ & Meta & Leg & I & Surgery & Regional (7) & Surgery & Surgery+RT (38) & AW & 54 & No \\
\hline $18 / 16$ & Primary & Ear & I & Surgery & Local (4) & Surgery & & AW & 36 & No \\
\hline $19 / 17$ & Primary & Nose & I & Surgery & $\begin{array}{l}\text { Local (11) } \\
\text { Regional (12) }\end{array}$ & RT (60) & & DOD & 49 & No \\
\hline $20 / 18$ & Primary & Nose & I & Surgery & Regional (4) & Surgery & & AW & 36 & No \\
\hline $21 / 19$ & Meta & Leg & I & Surgery & $\begin{array}{l}\text { Local (12) } \\
\text { Regional (36) }\end{array}$ & Surgery & Chemotherapy $^{\mathrm{a}}$ & DOD & 44 & Yes \\
\hline $22 / 20$ & Meta & Arm & I & Surgery & $\begin{array}{l}\text { Regional (2) } \\
\text { Metastasis (12) }\end{array}$ & Surgery & RT (50) & DOD & 24 & No \\
\hline $23 / 21$ & Primary & NA & I & Surgery & & & & AW & 25 & No \\
\hline $24 / 22$ & Primary & Cheek & I & Surgery & & & & AW & 89 & No \\
\hline $\begin{array}{l}25 / 22 \\
26 / 23\end{array}$ & $\begin{array}{l}\text { Meta } \\
\text { Primary }\end{array}$ & Chest & I & Suroery & & Suroerv+RT (62) & Suroerv+RT (25) & DOC & 17 & Yes \\
\hline 20120 & 1 111110 y & & & suigory & Metastasis (15) & 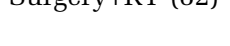 & जuाइण & DO & 17 & \\
\hline $27 / 24$ & Primary & Face & II & Surgery & Local (4) & Surgery & & AW & 82 & No \\
\hline $28 / 25$ & Meta & Leg & III & Surgery+RT (30) & & & & DOD & 8 & No \\
\hline $29 / 26$ & Primary & Neck & I & Surgery & & & & DOC & 17 & No \\
\hline $30 / 27$ & Meta & Face & I & Surgery & Regional (23) & Surgery & & DOD & 24 & No \\
\hline $31 / 28$ & Primary & Ear & I & Surgery & Metastasis (6) & Surgery+RT (30) & & DOD & 6 & Yes \\
\hline $32 / 29$ & Meta & Neck & I & Surgery & Metastasis (5) & & & AW & 109 & No \\
\hline
\end{tabular}

AW, alive and well; AWD, alive with disease; DOC, died of other cause; DOD, died of disease; IS, immunosuppression; Rec., recurrence; RT ( ), radiotherapy (dose in Gray); S/P, sample/patient number; site, site of primary tumor; TLF, time to last follow-up or death; NA, not available.

${ }^{\mathrm{a}}$ Cisplatin/Etoposide.

b Adriamycin, Cyclophosphamide, Vincristine.

${ }^{\mathrm{C}}$ Cyclophosphamide, Methotrexate, Fluorouracil.

${ }^{\mathrm{d}}$ Doxorubicin, Dacarbacine, Ifosfamide. 
Table 2 Antibodies and retrieval buffers for each antibody

\begin{tabular}{|c|c|c|c|c|c|}
\hline PDGF- $\alpha$ & NeoMarkers & RB-9027 & Rabbit & $1: 100$ & Citrate buffer \\
\hline PDGF- $\beta$ & NeoMarkers & RB-9032 & Rabbit & $1: 100$ & Citrate buffer \\
\hline VEGF-A & Pharmingen & ab3109 & Mouse & $1: 50$ & Citrate buffer \\
\hline VEGF-C & Zymed & $34-4300$ & Mouse & $1: 100$ & Citrate buffer \\
\hline VEGF-R2 & Santa Cruz & N-931 & Rabbit & $1: 80$ & EDTA buffer \\
\hline Bmi-1 & Upstate & $05-637$ & Mouse & $1: 300$ & EDTA buffer \\
\hline Mcl-1 & NeoMarkers & MS-681 & Mouse & $1: 200$ & Citrate buffer \\
\hline EGFR (EGF-R Zymed) & Invitrogen & 08-1205 & Mouse & RTU & Citrate buffer \\
\hline Her-2 (HercepTest) & Dako & K5204 & Rabbit & RTU & Citrate buffer \\
\hline C-kit (c-Kit pharmDx) & Dako & K1907 & & & \\
\hline
\end{tabular}

VEGF-A, vascular endothelial growth factor A; VEGF-C, vascular endothelial growth factor C; VEGF-R2, VEGF-receptor 2; PDGF- $\alpha$, plateletderived growth factor alpha; PDGF- $\beta$, platelet-derived growth factor beta; EGFR, epidermal growth factor receptor; c-erbB-2, HER-2/Neu; CD117, c-kit; Mcl-1, myeloid cell leukemia-1; Bmi-1, B-cell-specific moloney murine leukemia virus site 1; RTU, ready to use; EDTA, ethylenediaminetetraacetic acid.

usable tissue in each block. Each H\&E-stained slide was revaluated and mapped to identify the specific areas for tissue acquisition to build the tissue microarrays, which were constructed using the approach described by Kononen et $a{ }^{18}{ }^{18}$ using a Beecher manual tissue arrayer (MTA-1) (Beecher Instruments Inc., WI, USA). Core diameter was $0.6 \mathrm{~mm}$. Three cores were used per patient.

\section{Immunohistochemistry}

Dewaxed and rehydrated tissue microarrays were subjected to antigen retrieval in a microwave oven $(600 \mathrm{~W})$ employing the appropriate buffer (Table 2). Blocking of unspecific binding was achieved with $5 \%$ TBS/BSA (Sigma-Aldrich, Germany) for $1 \mathrm{~h}$ at room temperature. The primary antibody (Table 2) and appropriate negative and positive controls were applied at $4{ }^{\circ} \mathrm{C}$ overnight. A secondary biotinylated antibody (1:200, Multilink; Dako, Denmark) in 1\% TBS/BSA was included for $1 \mathrm{~h}$ at room temperature, followed by alkaline phosphatase-conjugated streptavidin-AP/TBS/BSA (1:250; Dako) for $1 \mathrm{~h}$ at room temperature. Visualization was performed by fast red (Sigma-Aldrich, St Louis, MO, USA) and counterstained by hemalaun. Samples were analyzed using an Olympus BH-2 microscope.

\section{Specimen Classification Based on Immunohistochemical Results and Morphological Features}

We used an immunoreactivity score proposed by Sinicrope et $a l^{19}$ to evaluate both the intensity of immunohistochemical staining and the proportion of the stained tumor cells. The staining intensity was subclassified as follows: 1, weak; 2, moderate; or 3 , strong. The positive cells were quantified as a percentage of the total number of tumor cells and the proportions were assigned to one of five categories: $0,<5 \% ; 1,5-25 \% ; 2,26-50 \% ; 3,51-75 \%$; and 4 , $>75 \%$. The percentage of positivity of the tumor cells and the staining intensity were then multiplied to generate the immunoreactivity score for each of
Table 3 Primers were designed as described in Materials and methods

\begin{tabular}{ll}
\hline C-kit exon & \\
\hline $\begin{array}{l}\text { Exon } 9(305 \mathrm{bp}) \\
\quad \text { Forward }\end{array}$ & \\
Reverse & $5^{\prime}$-ATTTATTTTCCTAGAGTAAGCCAGGG-3' \\
& $5^{\prime}$-ATCATGACTGATATGGTAGACAGAGC-3' \\
Exon $11(247 \mathrm{bp})$ & \\
Forward & \\
Reverse & $5^{\prime}$-CCAGAGTGCTCTAATGACTG-3' \\
& $5^{\prime}$-CTGTTATGTGTACCCAAAAAGG-3'
\end{tabular}

bp, base pairs.

the tumor specimens. Mean immunoreactivity score was calculated from the three samples per patient. The expression pattern of each marker in the complete tumor samples was determined independently by two experienced investigators (MB and $\mathrm{BME}$ ). An attempt to avoid observer bias was made by repeating the evaluation of protein expression at two different time points and without knowledge of patients' clinical data.

\section{DNA Sequence Analysis}

Isolation of DNA from paraffin-embedded tumor tissue

Genomic DNA was prepared from 4- to 8.5- $\mu$ m-thick sections of c-kit-positive paraffin-embedded tumor material using the QIAamp DNA Mini kit (Qiagen, Hilden, Germany). Paraffin blocks were trimmed to minimize the amount of non-neoplastic tissue before sectioning. A $100 \mathrm{ng}$ portion of genomic DNA was amplified in $50 \mu \mathrm{l}$ PCR mixtures using BD Advantage 2 (Clonetech; BD Biosciences, Erembodegem, Belgium) according to the manufacturers' instructions.

\section{Design of primers}

Primers specific for c-kit exons 9 and 11 were designed with the use of Primer Designer Software (Scientific and Education Software, Durham, NC, USA). The primers used are listed in Table 3. 
PCR and DNA sequence analysis

PCR was performed using the AmpliTaq Gold kit (Applied Biosystems, Darmstadt, Germany). Bidirectional sequencing of PCR products was performed using BigDye 1.1 terminator chemistry (Applied Biosystems, Foster City, CA, USA) and an ABI3130 Sequencer (Applied Biosystems). For BigDyeTerminator removal, sequenced PCR products were cleaned up before analysis using Sigma Post-Reaction Clean-Up plates (Sigma-Aldrich, St Louis, MO, USA) according to the manufacturers' recommendations.

\section{Statistical Analysis}

To assess the correlation between target expression and tumor remission, sex and tumor stage univariate and multivariate stepwise logistic analyses were performed. The Statistical Package for the Social Sciences Software, Version 11.5 for Windows (SPSS UK Ltd, Surrey, UK), was used for analysis. A $P$-value $<0.05$ (two-sided) was considered as statistically significant.

\section{Results}

\section{Clinical Data}

Of the 29 patients, 17 (59\%) were male and 12 (41\%) were female, ranging in age from 50 to 96 years (mean 76.8 years). Nineteen tumors (66\%) were located in the head and neck region and $10(34 \%)$ on the extremities. Twenty-three patients (79\%) presented with early disease (stage I), four with stage II (14\%) and two with stage III (7\%). Eleven (40\%) are alive without disease and two $(7 \%)$ are alive with disease. Eleven died of the disease $(40 \%)$ and five died of other causes (13\%). Table 1 shows the complete clinical data.

\section{Microscopy}

As described previously by Sur et $a l,{ }^{20}$ we observed two distinct types of Merkel cell carcinoma cells. Nine samples showed morphology similar to classical small cell carcinoma. In 18 samples, the carcinoma cells were significantly bigger (larger than 3 lymphocytes) and showed high mitotic activity and multiple nucleoli. In five samples, both morphologies were present.

\section{Immunohistochemistry}

Interestingly, with the exception of c-kit, the investigated proteins were usually uniformly expressed in all tumor cells (Figure 1).

\section{c-kit}

Two out of 32 (7\%) Merkel cell carcinoma samples were positive for c-kit. Both samples belonged to the same patient and showed a membranous staining pattern in a small number of tumor cells. Immunoreactivity score was 2.7 in one and 3.7 (mean 3.2) in the other sample. Both samples belonged to the large cell carcinoma group.

\section{$\mathrm{Mcl}-1$}

Out of 32 samples, 25 (88\%) were positive for Mcl-1 in the cell cytoplasm. Mean immunoreactivity score of the positive samples was 6.4. There was no significant difference between small and large cells.

\section{Bmi-1}

Out of 32 samples, 24 (75\%) were positive for Bmi-1 in the cell nuclei and cytoplasm. Mean immunoreactivity score of the positive samples was 8 . There was no significant difference between small and large cells.

\section{VEGF-A}

Out of 32 samples, 29 (91\%) were positive for VEGF$A$ in the cell cytoplasm. Although almost all samples expressed VEGF-A, the staining intensity was generally low with a mean immunoreactivity score of 4.7. There was no significant difference between small and large cells.

\section{VEGF-C}

Out of 32 samples, 24 (75\%) were positive for VEGF-C in the cell cytoplasm. As with VEGF-A, the mean staining intensity was relatively low with an immunoreactivity score of 4.4. There was no significant difference between small and large cells.

\section{VEGF-R2}

Out of 32 samples, 28 (88\%) were positive for VEGFR2 with a membranous and cytoplasmic staining pattern. Almost all samples expressed VEGF-R2, some samples with a very high intensity. The mean immunoreactivity score of the positive samples was 8.6. VEGF-R2 expression was higher in the large cell group, although the difference failed to reach statistical significance $(P=0.007)$.

\section{$P D G F-\beta$}

Only 4 samples out of 32 (13\%) expressed PDGF- $\beta$ in the cell cytoplasm. All of those samples belonged to the large cell group. Two samples were with an intensity score of 4 and two with a score of 8 (mean 6).

\section{$P D G F-\alpha$}

Out of 32 samples, $23(72 \%)$ were positive for PDGF- $\alpha$ with a partially cytoplasmic and partially membranous staining pattern. The mean immunoreactivity score of the positive samples was 4.7. There was no significant difference between small and large cells.

Immunohistochemistry showed no positive staining for EGFR and Her-2/Neu. Staining pattern of all antibodies is shown in Figure 2.

\section{DNA Sequence Analysis}

Paraffin-embedded samples of the two c-kit-positive tumors were screened for mutations in hot-spot 

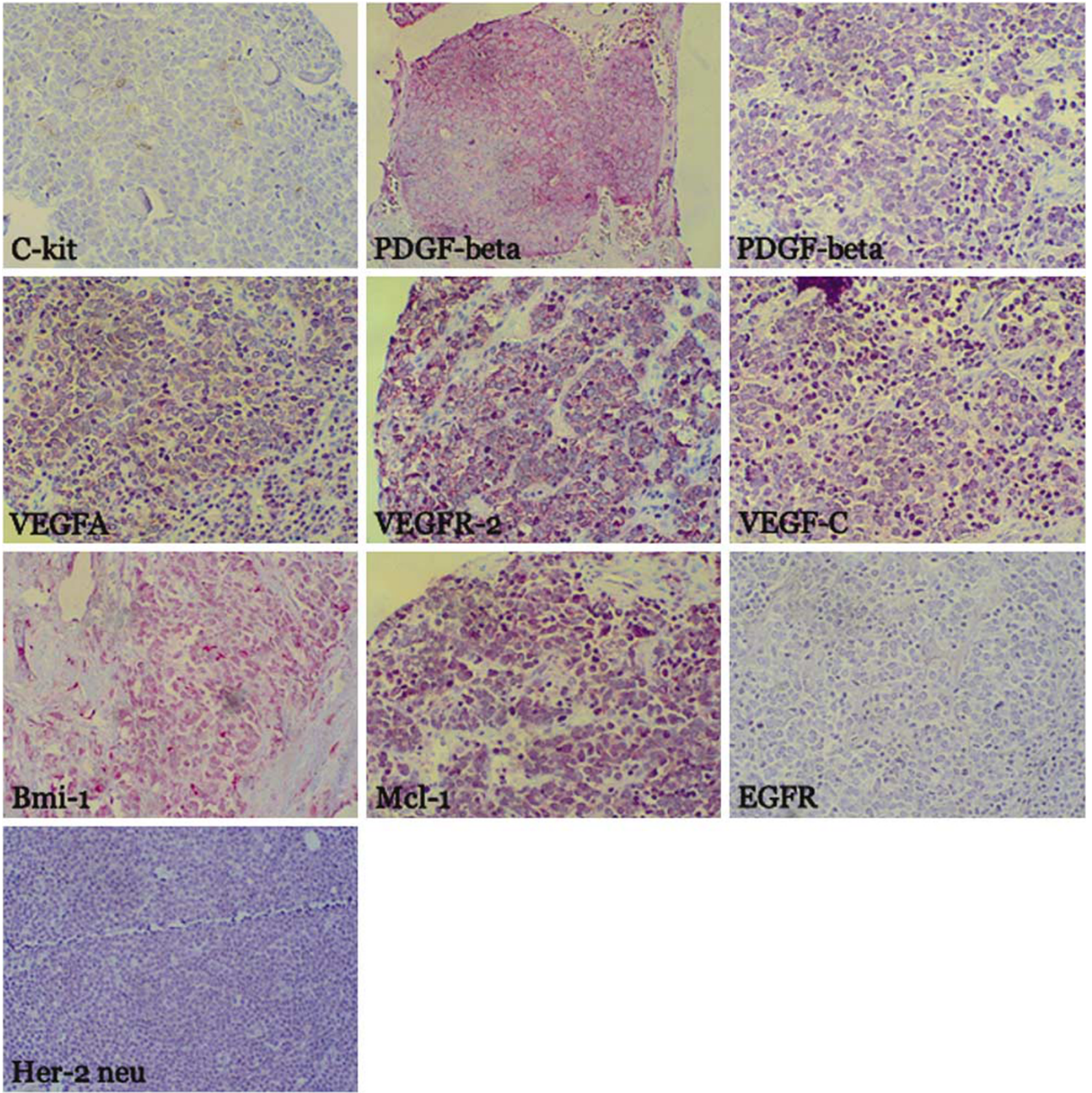

Figure 1 Immunostaining of target proteins in a tissue microarray of Merkel cell carcinomas. C-kit IHC showed the typical membranous staining pattern and was slightly positive in only two samples. PDGF- $\alpha$, PDGF- $\beta$, VEGF-C, VEGF-A, VEGF-R2 and Mcl-1 were mainly expressed in the cell cytoplasm, whereas Bmi-1 showed a predominantly nuclear staining pattern. The PDGF- $\beta$ stain represents one of the few samples where the protein was expressed only in parts of the tumor-in the majority of samples, we found a very uniform expression throughout the cores. IHC, immunohistochemistry.

regions of c-kit (exons 9 and 11). However, no mutations leading to amino-acid changes in the mature protein could be detected.

\section{Correlation of Target Expression and Clinical Outcome}

Statistical analysis revealed no correlation between target expression and tumor remission, gender and tumor stage.

\section{Discussion}

Merkel cell carcinoma, a neuroendocrine neoplasm, is a highly proliferative epidermal tumor with a high rate of recurrence and metastasis and poor survival. Current treatment options did not significantly improve patients overall survival. Thus, advances in therapy will depend on novel therapeutic approaches. During the last decade, 

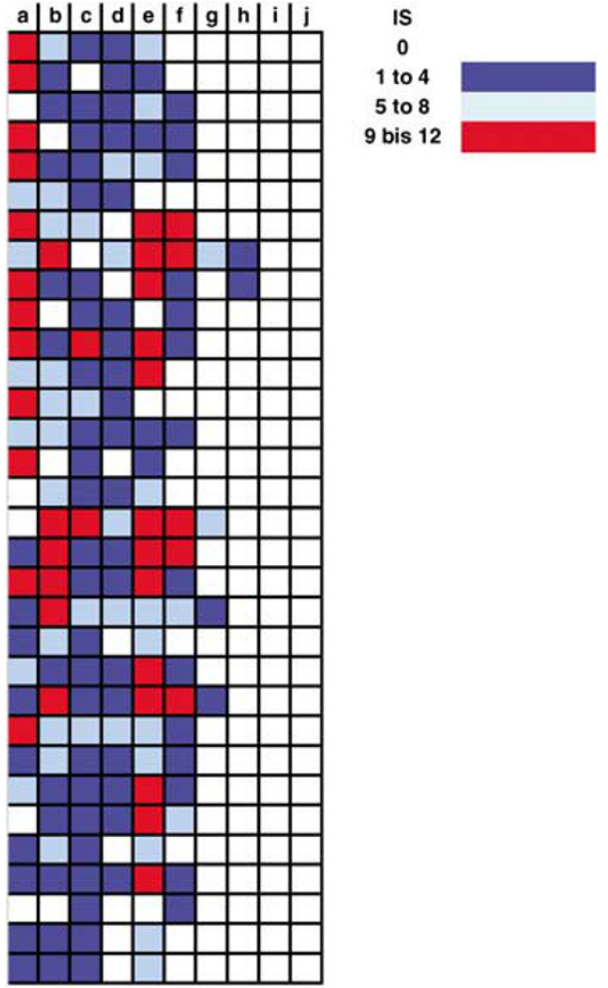

Figure 2 A schematic representation of the expression pattern of the tested antigens in Merkel cell carcinoma: (a) Bmi-1, (b) Mcl-1, (c) VEGF-A, (d) VEGF-C, (e) VEGF-R2, (f) PDGF- $\alpha$, (g) PDGF- $\beta$, (h) c-kit, (i) EGFR and (j) Her-2/Neu. The expression level of individual cases represented by immunoreactivity score (IS) is shown in colors.

several potential marker proteins as potential anticancer targets have been discovered.

A frequently utilized group of targets of new signal-transduction agents is the protein kinase signalling network. One mode of attenuation is to block the ligand binding domain. This domain is the target of two antibodies in clinical use, Trastuzumab and Cetuximab. Trastuzumab (Herceptin ${ }^{\mathbb{R}}$ ) is directed against the erbB-2 receptor, which is also known as Her-2/Neu oncogene. Cetuximab (Erbitux ${ }^{\circledR}$ ) is active against the EGFR. In our samples, Merkel cell carcinoma cells did neither express EGFR nor Her-2/ Neu. Thereby, we could confirm the findings of Maubec et al, ${ }^{21}$ who also could not detect any expression of these two receptors in Merkel cell carcinoma by immunohistochemistry.

The next group of targets in the protein kinase signalling network is receptor tyrosine kinases. Receptor tyrosine kinases are single-pass membrane proteins with an extracellular ligand binding and an intracellular kinase domain. Receptor tyrosine kinases function in cell signalling and transmit signals regulating growth, differentiation, adhesion, migration and apoptosis. ${ }^{22-26}$ The receptor tyrosine kinase family consists of several subfamilies, including the epidermal growth factor receptors (EGFRs or ErbBs), the platelet-derived growth factor receptors (PDGFRs) and the VEGF receptors. ${ }^{23}$ All of the above-mentioned subfamilies are known to be expressed in many cancers and play an important role in angiogenesis and tumor progression. ${ }^{27,28} \mathrm{In}$ this study, we observed that VEGF-A, VEGF-C, VEGF-R2, PDGF- $\alpha$ and PDGF- $\beta$ are expressed in Merkel cell carcinomas. Interestingly, all of the examined proteins were uniformly expressed throughout the tumors and their expression levels were rather low. There was a tendency toward higher expression in large cell tumors, although the difference did not reach statistical significance. This discrepancy was most pronounced in VEGF-R2. Furthermore, in most of the investigated samples VEGF-R2 was detectable in the cell cytoplasm and its expression level was significantly higher than that of the above-mentioned proteins. The reason for the differential expression of receptor tyrosine kinases in Merkel cell carcinoma is still unknown.

C-kit, a proto-oncogene involved in the activation of cell proliferation, is expressed not only in normal cells $^{29}$ but also in tumors of the solid aerodigestive tract. $^{30-32}$ The expression of c-kit (CD117) in Merkel cell carcinoma has been examined previously in five studies with a range of $15-95 \% .{ }^{11-16}$ In our study, $7 \%$ of Merkel cell carcinoma samples expressed c-kit. We hypothesize that the discrepancy between the five studies can be explained by the small sample numbers and by different staining and evaluation methods utilized.

C-kit and VEGF-R2, together with VEGF-R1, VEGF-R3 and PDGFRs, are targets of two multitargeted inhibitors Sorafenib (Nexavar ${ }^{\mathbb{R}}$ ) and Sunitinib (Sutent ${ }^{\circledR}$ ). Sunitinib has been successfully tested in the treatment of renal cell carcinoma ${ }^{7,8}$ and gastrointestinal stromal tumors. ${ }^{9,10}$ Sorafenib is an effective anticancer agent directed against renal cell carcinoma ${ }^{33,34}$ and has been evaluated in phase I trials in solid tumors, melanoma and non-small-cell lung cancer. ${ }^{35-37}$ In gastrointestinal stromal tumors, different c-kit mutations are known to predict survival and even more importantly response to treatment with tyrosine kinase inhibitors. ${ }^{38,39}$

The exons of c-kit that are most commonly affected by mutation are exons 9 and 11. Gastrointestinal stromal tumors with exon 11 mutations respond more frequently to targeted treatment than exon 9 mutations, while wild-type c-kit has the worst response rate. ${ }^{38,39}$ In two c-kit-positive samples of our study, no mutations leading to aminoacid changes in the mature protein could be detected. Based on our analysis of c-kit expression and mutation, c-kit does not seem to be a very promising candidate for targeted anticancer therapy in Merkel cell carcinoma.

Another way to affect tumor growth is to inhibit the expression of genes involved in cell proliferation and cell death by introduction of microRNAs or antisense oligonucleotides. ${ }^{40}$ Recently, several antisense oligonucleotides targeting genes involved in neoplastic progression have been evaluated as potential therapeutic agents, one of them being 
Mcl-1. ${ }^{41-43}$ Mcl-1, a member of the Bcl-2 protein family, is an antiapoptotic protein ${ }^{4-46}$ and functions by avoiding cell damage-induced mitochondrial cytochrome $C$ release. ${ }^{47,48}$ Although the definite mechanisms of how Mcl-1 promotes cell survival is not yet fully elucidated, the biological significance of Mcl-1 protein expression in supporting cell survival has been well documented in a number of solid and non-solid tumors. ${ }^{41,49-55}$ Therefore, the next logical step was specific inhibition of Mcl-1 expression by antisense oligonucleotides or microRNAs. ${ }^{55}$ So far no study has investigated the expression of Mcl-1 in Merkel cell carcinoma. In our cohort, the majority of tumor samples showed a very high expression of Mcl-1. That makes Mcl-1 a very auspicious candidate for targeted therapy and validates further in vivo studies on the effect of Mcl-1 antisense oligonucleotides in Merkel cell carcinoma.

Bmi-1 is a transcriptional repressor that belongs to the polycomb-group family of proteins involved in hematopoiesis, regulation of proliferation and axial patterning. ${ }^{56,57}$ It has been found to be an important factor of self-renewal and senescence of various stem cells, ${ }^{58-60}$ and its overexpression was shown to immortalize human mammary epithelial cells. ${ }^{61}$ Bmi-1 is highly expressed in various human malignant tumors. ${ }^{62-69}$ The recently developed antisense Bmi-1 expression plasmid was able to inhibit proliferation of human leukemia cells in vitro. ${ }^{70}$ Interestingly, we were able to demonstrate intense Bmi-1 expression in almost all Merkel cell carcinoma specimens of our cohort. That makes Bmi-1 another promising candidate for future antisense oligonucleotide therapies in patients with Merkel cell carcinoma.

Owing to the small number of tumor specimens, we could not detect any statistically relevant correlations between patients' clinical data and target expression. Also, we could not demonstrate an impact of the morphology on the course and aggressiveness of the disease. However, further studies will be needed to fully determine the impact of targeted therapy in Merkel cell carcinoma in vitro and in vivo, as the presence of a target does not always predict response to a targeted agent. ${ }^{71}$

In summary, in this study we show for the first time that the therapy targets c-kit, Bmi-1, Mcl-1, VEGF-A and VEGF-C, VEGF-R2, PDGF- $\alpha$ and PDGF$\beta$ are expressed in Merkel cell carcinoma. Considering the good results of targeted anticancer and antiangiogenic therapies in resent clinical trials, these results are very promising and validate further clinical studies on the use of multitargeted tyrosine kinase inhibitors and antisense oligonucleotides in Merkel cell carcinoma.

\section{Acknowledgement}

This work was supported by the Grant 'Fellinger Krebsforschung, Verein zur Förderung der Krebsforschung, Vienna,' Austria.

\section{Disclosure/conflict of interest}

The authors have no conflict of interest to declare.

\section{References}

1 Miller RW, Rabkin CS. Merkel cell carcinoma and melanoma: etiological similarities and differences. Cancer Epidemiol Biomarkers Prev 1999;8:153-158.

2 Agelli M, Clegg LX. Epidemiology of primary Merkel cell carcinoma in the United States. J Am Acad Dermatol 2003;49:832-841.

3 Veness MJ. Merkel cell carcinoma (primary cutaneous neuroendocrine carcinoma): an overview on management. Australas J Dermatol 2006;47:160-165.

4 Poulsen M, Rischin D, Walpole E, et al. High risk Merkel cell carcinoma of the skin treated with synchronous carboplatin/etoposide and radiation: a Trans-Tasman Radiation Oncology Group study-TROG 96:07. J Clin Oncol 2003;21:4371-4376.

5 Poulsen MG, Rischin D, Porter I, et al. Does chemotherapy improve survival in high risk stage I and II Merkel cell carcinoma of the skin? Int J Radiat Oncol Biol Phys 2006;64:114-119.

6 Suarez C, Rodrigo JP, Ferlito A, et al. Merkel cell carcinoma of the head and neck. Oral Oncol 2004;40: 773-779.

7 Motzer RJ, Rini BI, Bukowski RM, et al. Sunitinib in patients with metastatic renal cell carcinoma. JAMA 2006;295:2516-2524.

8 Motzer RJ, Michaelson MD, Redman BG, et al. Activity of SU11248, a multitargeted inhibitor of vascular endothelial growth factor receptor and platelet-derived growth factor receptor, in patients with metastatic renal cell carcinoma. J Clin Oncol 2006;24:16-24.

9 Demetri GD, van Oosterom AT, Garrett CR, et al. Efficacy and safety of sunitinib in patients with advanced gastrointestinal stromal tumour after failure of imatinib: a randomised controlled trial. Lancet 2006;14:1329-1338.

10 DeMatteo RP, Maki RG, Singer S, et al. Results of tyrosine kinase inhibitor therapy followed by surgical resection for metastatic gastrointestinal stromal tumor. Ann Surg 2007;245:347-352.

11 Bobos M, Hytiroglou P, Kostopoulos I, et al. Immunohistochemical distinction between Merkel cell carcinoma and small cell carcinoma of the lung. Am J Dermatopathol 2006;28:99-104.

12 Pradeep CR, Sunila ES, Kuttan G. Expression of vascular endothelial growth factor (VEGF) and VEGF receptors in tumor angiogenesis and malignancies. Integr Cancer Ther 2005;4:315-321.

13 Feinmesser M, Halpern M, Kaganovsky E, et al. C-kit expression in primary and metastatic Merkel cell carcinoma. Am J Dermatopathol 2004;26:458-462.

14 Strong S, Shalders K, Carr R, et al. KIT receptor (CD117) expression in Merkel cell carcinoma. Br J Dermatol 2004;150:384-385.

15 Su LD, Fullen DR, Lowe L, et al. CD117 (KIT receptor) expression in Merkel cell carcinoma. Am J Dermatopathol 2002;24:289-293.

16 Swick BL, Ravdel L, Fitzpatrick JE, et al. Merkel cell carcinoma: evaluation of KIT (CD117) expression and failure to demonstrate activating mutations in the CKIT proto-oncogene-implications for treatment with imatinib mesylate. J Cutan Pathol 2007;34:324-329. 
17 Yiengpruksawan A, Coit DG, Thaler HT, et al. Merkel cell carcinoma. Prognosis and management. Arch Surg 1991;126:1514-1519.

18 Kononen J, Bubendorf L, Kallioniemi A, et al. Tissue microarrays for high-throughput molecular profiling of tumor specimens. Nat Med 1998;4:844-847.

19 Sinicrope FA, Ruan SB, Cleary KR, et al. bcl-2 and p53 oncoprotein expression during colorectal tumorigenesis. Cancer Res 1995;15:237-241.

20 Sur M, Alardati H, Ross C, et al. TdT expression in Merkel cell carcinoma: potential diagnostic pitfall with blastic hematological malignancies and expanded immunohistochemical analysis. Mod Pathol 2007;20: 1113-1120.

21 Maubec E, Duvillard P, Velasco V, et al. Immunohistochemical analysis of EGFR and HER-2 in patients with metastasizing melanoma, Merkel carcinoma and squamous cell carcinoma of the skin. Ann Dermatol Venereol 2006;133:274-276.

22 Blume-Jensen P, Hunter T. Oncogenic kinase signalling. Nature 2000;411:355-365.

23 Robertson SC, Tynan JA, Donoghue DJ. RTK mutations and human syndromes: when good receptors turn bad. Trends Genet 2000;16:265-271.

24 Schlessinger J. Cell signaling by receptor tyrosine kinases. Cell 2000;103:211-225.

25 Verschuur HP, Rijksen G, Slootweg PJ, et al. Aberrant tyrosine phosphorylation in head and neck tumours and potentially premalignant tissues. Acta Otolaryngol 1995;115:326-327.

26 Zwick E, Bange J, Ullrich A. Receptor tyrosine kinases as targets for anticancer drugs. Trends Mol Med 2002; 8:17-23

27 Takahashi H, Shibuya M. The vascular endothelial growth factor (VEGF)/VEGF receptor system and its role under physiological and pathological conditions. Clin Sci 2005;109:227-241.

28 Alvarez RH, Kantarjian HM, Cortes JE. Biology of platelet-derived growth factor and its involvement in disease. Mayo Clin Proc 2006;81:1241-1257.

29 Natali PG, Nicotra MR, Sures I, et al. Expression of c-kit receptor in normal and transformed human nonlymphoid tissues. Cancer Res 1992;52:6139-6143.

30 Ikeda H, Kanakura Y, Tamaki T, et al. Expression and functional role of the protooncogene c-kit in acute myeloblastic leukemia cells. Blood 1991;78: 2962-2968.

31 Krystal GW, Hines SJ, Organ CP. Autocrine growth of small cell lung cancer mediated by coexpression of c-kit and stem cell factor. Cancer Res 1996;56:370-376.

32 Nakahara M, Isozaki K, Hirota S, et al. A novel gainof-function mutation of c-kit gene in gastrointestinal stromal tumors. Gastroenterology 1998;115: 1090-1095.

33 Escudier B, Eisen T, Stadler WM, et al. Sorafenib in advanced clear-cell renal-cell carcinoma. N Engl J Med 2007;11:125-134.

34 Ratain MJ, Eisen T, Stadler WM, et al. Phase II placebocontrolled randomized discontinuation trial of sorafenib in patients with metastatic renal cell carcinoma. J Clin Oncol 2006;24:2505-2512.

35 Adjei AA, Mandrekar S, Marks RS, et al. A phase I study of BAY 43-9006 and gefitinib in patients with refractory or recurrent non-small-cell lung cancer (NSCLC). Proc Am Soc Clin Oncol 2005;23:3067.

36 Eisen T, Ahmad T, Gore ME, et al. Phase I trial of BAY 43-9006 (sorafenib) combined with dacarbazine (DTIC) in metastatic melanoma patients [abstract]. Proc Am Soc Clin Oncol 2005;23:7508.

37 Mross K, Steinbild S, Baas F, et al. Results from an in vitro and a clinical/pharmacological phase I study with the combination irinotecan and sorafenib. Eur J Cancer 2007;43:55-63.

38 Andersson J, Bumming P, Meis-Kindblom JM, et al. Gastrointestinal stromal tumors with KIT exon 11 deletions are associated with poor prognosis. Gastroenterology 2006;130:1573-1581.

39 Tornillo L, Terracciano LM. An update on molecular genetics of gastrointestinal stromal tumours. J Clin Pathol 2006;59:557-563.

40 Dean NM, Bennett CF. Antisense oligonucleotidebased therapeutics for cancer. Oncogene 2003;22: 9087-9096.

41 Cho-Vega JH, Rassidakis GZ, Admirand JH, et al. MCL1 expression in B-cell non-Hodgkin's lymphomas. Hum Pathol 2004;35:1095-1100.

42 Gleave M, Monia BP. Antisense therapy for cancer. Nat Rev Cancer 2005;5:468-479.

43 Ziegler A, Luedke GH, Fabbro D, et al. Induction of apoptosis in small-cell lung cancer cells by an antisense oligodeoxynucleotide targeting the Bcl-2 coding sequence. J Natl Cancer Inst 1997;89: 1027-1036.

44 Krajewski S, Bodrug S, Krajewska M, et al. Immunohistochemical analysis of Mcl-1 protein in human tissues. Differential regulation of Mcl-1 and Bcl-2 protein production suggests a unique role for Mcl-1 in control of programmed cell death in vivo. Am J Pathol 1995;146:1309-1319.

45 Wacheck V, Cejka D, Sieghart W, et al. Mcl-1 is a relevant molecular target for antisense oligonucleotide strategies in gastric cancer cells. Cancer Biol Ther 2006;5:1348-1354.

46 Yang T, Kozopas KM, Craig RW. The intracellular distribution and pattern of expression of Mcl-1 overlap with, but are not identical to, those of Bcl-2. J Cell Biol 1995;128:1173-1184.

47 Akgul C, Turner PC, White MR, et al. Functional analysis of the human MCL-1 gene. Cell Mol Life Sci 2000;57:684-691.

48 Kozopas KM, Yang T, Buchan HL, et al. MCL1, a gene expressed in programmed myeloid cell differentiation, has sequence similarity to BCL2. Proc Natl Acad Sci USA 1993;90:3516-3520.

49 Backus $\mathrm{HH}$, van Riel JM, van Groeningen CJ, et al. Rb, Mcl-1 and p53 expression correlate with clinical outcome in patients with liver metastases from colorectal cancer. Ann Oncol 2001;12:779-785.

50 Chung TK, Cheung TH, Lo WK, et al. Expression of apoptotic regulators and their significance in cervical cancer. Cancer Lett 2004;180:63-68.

51 Derenne S, Monia B, Dean NM, et al. Antisense strategy shows that Mcl-1 rather than Bcl-2 or $\mathrm{Bcl}-\mathrm{x}(\mathrm{L})$ is an essential survival protein of human myeloma cells. Blood 2002;100:194-199.

52 Khoury JD, Medeiros LJ, Rassidakis GZ, et al. Expression of Mcl-1 in mantle cell lymphoma is associated with high-grade morphology, a high proliferative state, and p53 overexpression. J Pathol 2001;199:90-97.

53 Miyamoto Y, Hosotani R, Wada M, et al. Immunohistochemical analysis of Bcl-2, Bax, Bcl-X, and Mcl-1 expression in pancreatic cancers. Oncology 1999;56: 73-82. 
54 Sieghart W, Losert D, Strommer S, et al. Mcl-1 overexpression in hepatocellular carcinoma: a potential target for antisense therapy. J Hepatol 2006;44: 151-157.

55 Mott JL, Kobayashi S, Bronk SF, et al. mir-29 regulates Mcl-1 protein expression and apoptosis. Oncogene 2007;26:6133-6140.

56 van der Lugt NM, Domen J, Linders K, et al. Posterior transformation, neurological abnormalities, and severe hematopoietic defects in mice with a targeted deletion of the Bmi-1 proto-oncogene. Genes Dev 1994;8: 757-769.

57 Pirrotta V. Polycombing the genome: PcG, trxG, and chromatin silencing. Cell 1998;93:333-336.

58 Jacobs JJ, Kieboom K, Marino S, et al. The oncogene and polycomb-group gene Bmi-1 regulates cell proliferation and senescence through the ink4a locus. Nature 1999;397:164-168.

59 Liu S, Dontu G, Wicha MS. Mammary stem cells, selfrenewal pathways, and carcinogenesis. Breast Cancer Res 2005;7:86-95.

60 Wang Y, Schulte BA, Zhou D. Hematopoietic stem cell senescence and long-term bone marrow injury. Cell Cycle 2006;5:35-38.

61 Dimri GP, Martinez JL, Jacobs JJ, et al. The Bmi-1 oncogene induces telomerase activity and immortalizes human mammary epithelial cells. Cancer Res 2002;62:4736-4745.

62 Bea S, Tort F, Pinyol M, et al. BMI-1 gene amplification and overexpression in hematological malignancies occur mainly in mantle cell lymphomas. Cancer Res 2001;61:2409-2412.

63 Glinsky GV, Berezovska O, Glinskii AB. Microarray analysis identifies a death-from cancer signature predicting therapy failure in patients with multiple types of cancer. J Clin Invest 2005;115:1503-1521.

64 van Kemenade FJ, Raaphorst FM, Blokzijl T, et al. Coexpression of BMI-1 and EZH2 polycomb-group proteins is associated with cycling cells and degree of malignancy in B cell non-Hodgkin lymphoma. Blood 2001;97:3896-3901.

$65 \mathrm{Kim} \mathrm{JH}$, Yoon SY, Kim CN, et al. The Bmi-1 oncoprotein is overexpressed in human colorectal cancer and correlates with the reduced p16INK4a/ p14ARF proteins. Cancer Lett 2004;203:217-224.

$66 \mathrm{Kim} \mathrm{JH}$, Yoon SY, Jeong SH, et al. Overexpression of Bmi-1 oncoprotein correlates with axillary lymph node metastases in invasive ductal breast cancer. Breast 2004;13:383-388.

67 Reinisch C, Kandutsch S, Uthman A, et al. BMI-1: a protein expressed in stem cells, specialized cells and tumors of the gastrointestinal tract. Histol Histopathol 2006;21:1143-1149.

68 Song LB, Zeng MS, Liao WT, et al. Bmi-1 is a novel molecular marker of nasopharyngeal carcinoma progression and immortalizes primary human nasopharyngeal epithelial cells. Cancer Res 2006;66:6225-6232.

69 Vonlanthen S, Heighway J, Altermatt HJ, et al. The Bmi-1 oncoprotein is differentially expressed in nonsmall cell lung cancer and correlates with INK4A-ARF locus expression. Br J Cancer 2001;84:1372-1376.

70 Meng XX, Liu WH, Liu DD, et al. Construction of antisense Bmi-1 expression plasmid and its inhibitory effect on K562 cells proliferation. Chin Med J 2005; 118:1346-1350.

71 Bergsland EK. When does the presence of the target predict response to the targeted agent? J Clin Oncol 2006;24:213-216. 